\title{
Study of the Effects of High Levels of Nutrients on Seed Germination and Root Elongation
}

\author{
János Tamás Kundrát ${ }^{1}$, István Gyulai ${ }^{2}$, Edina Simon ${ }^{1 *}$, \\ Edvárd Mizsei ${ }^{3}$, Mihály Braun ${ }^{4}$, Béla Tóthmérész ${ }^{5}$ \\ ${ }^{1}$ Department of Ecology, University of Debrecen, Debrecen, \\ Egyetem tér 1, H-4032 Hungary \\ ${ }^{2}$ Department of Hydrobiology, University of Debrecen, Debrecen, \\ Egyetem tér 1, H-4032 Hungary \\ ${ }^{3}$ Department of Evolutionary Zoology and Human Biology, University of Debrecen, Debrecen, \\ Egyetem tér 1, H-4032 Hungary \\ ${ }^{4}$ Institute of Nuclear Research of the Hungarian Academy of Sciences, Hertelendi Laboratory \\ of Environmental Studies, Debrecen, Bem tér 18/C, H- 4026 Hungary \\ ${ }^{5}$ MTA-DE Biodiversity and Ecosystem Services Research Group, Debrecen, Egyetem tér 1, H-4032, Hungary
}

Received: 20 December 2016

Accepted: 8 February 2017

\begin{abstract}
Plant seeds are highly sensitive to environmental stress. The aim of our paper was to assess the effects of high nutrient levels in the water and sediment of thermal ponds and rivers on the ecosystem, based on the seed germination and root elongation of $S$. alba in the Lëngaricës Valley, Albania. Significant differences were found in the physicochemical parameters of the water and the sediment among samples taken from the river, the thermal ponds, and the control ponds. We found significant differences in the root elongation of $S$. alba seeds based on the water and the sediment of the river, the thermal ponds, and the control ponds. Significantly longer roots were found in the thermal water and sediment than in the river. Among the physicochemical parameters of the water and the sediment, $\mathrm{Cu}, \mathrm{K}$, and $\mathrm{Li}$ were stimulants for root elongation. With $\mathrm{Cu}, \mathrm{Li}, \mathrm{Ba}, \mathrm{Mg}, \mathrm{Ni}$, carbon-dioxide, and sulphate-ion, a stimulant effect was found on seed germination. Our results indicated that the high mineral level of the water and sediment of these thermal ponds had positive effects on the ecosystem based on seed germination and the root elongation test of $S$. alba.
\end{abstract}

Keywords: Sinapis alba, stimulant effects, physicochemical parameters

\section{Introduction}

Spring and thermal ponds are important elements of a landscape, and thermal water is among the best

*e-mail: edina.simon@gmail.com environmental geoindicators [1-2]. Earlier studies have demonstrated that the chemistry of thermal ponds is largely influenced by the specific geological setting [2]. The use of thermal water for geochemical energy and improving health is also important [3]. Many earlier studies have demonstrated that thermal water has effects on the human body, e.g., on skin regeneration and the 
antioxidant system [3-4]. But the effect of thermal water on the aquatic ecosystem has rarely been studied.

Plant seeds are highly sensitive to environmental stress. Root elongation methods are commonly used in toxicity tests to assess the effects of environmental contamination on ecosystems [5]. A toxicology test with seed germination and root elongation is a useful method during environmental biomonitoring [6]. This method was developed to assess the toxicity of polluted liquids on seed germination and root elongation [7]. Wierzbicka and Obidzinska [8] demonstrated that seed coats were the main barrier to contaminants, and prevent contamination of embryos until the seed coat is torn apart by the germinating embryonic root. Germination of seeds may depend on such parameters as the seed structure and seed coats [9]. Plant species are recommended by the U.S. Environmental Protection Agency (EPA) and the Organization for Economic Cooperation and Development (OECD). Many earlier studies have demonstrated that white mustard (Sinapis alba L.) seeds are especially useful for toxicology tests [10-12]. The short germination period and fast growth of $S$. alba seeds are among the advantages of these tests.

We studied the differences among the physical and chemical parameters of the water and sediments of rivers, and thermal and control ponds. The negative effect of high levels of some nutrients on human health and on aquatic and terrestrial organisms was also a commonly known fact [13]. Thus, our hypothesis was that not all media with high concentrations of nutrients may be toxic and that the effects of high concentrations of nutrients may depend on an exceptional content and composition of nutrients in the water or bottom sediments of thermal ponds. Therefore, the aim of our study was to test whether the high level of nutrients in water and sediment may have toxic and/ or stimulant effects on seed germination and the root elongation test.

\section{Materials and Methods}

The Lëngaricës Valley is in southern Albania, in the Permet region. The Lëngaricës River snakes along the region's calcareous and orogenous formations. There are thermal ponds on both sides of the river close to Bënja village [14]. Five thermal ponds were studied in August 2011. These ponds - named (with one exception) according to their effects on the human body - are the Thermal Pond of the Priest, the Thermal Pond of the Stomach, the Thermal Pond of the Skin, and the Thermal Pond of Rheumatism [15]. The Lëngaricës, together with these thermal ponds, flows near the village of Bënja. Two control (C1-C2) samples were used as far as the thermal ponds are concerned (Fig. 1). The thermal pond samples are referred to as T1-T2-T3-T4-T5. The distance between the first and the fifth thermal ponds is no more than a few hundred meters. The river samples are referred to as R1-R2-R3-R4-R5-R6-R7; samples are named after the

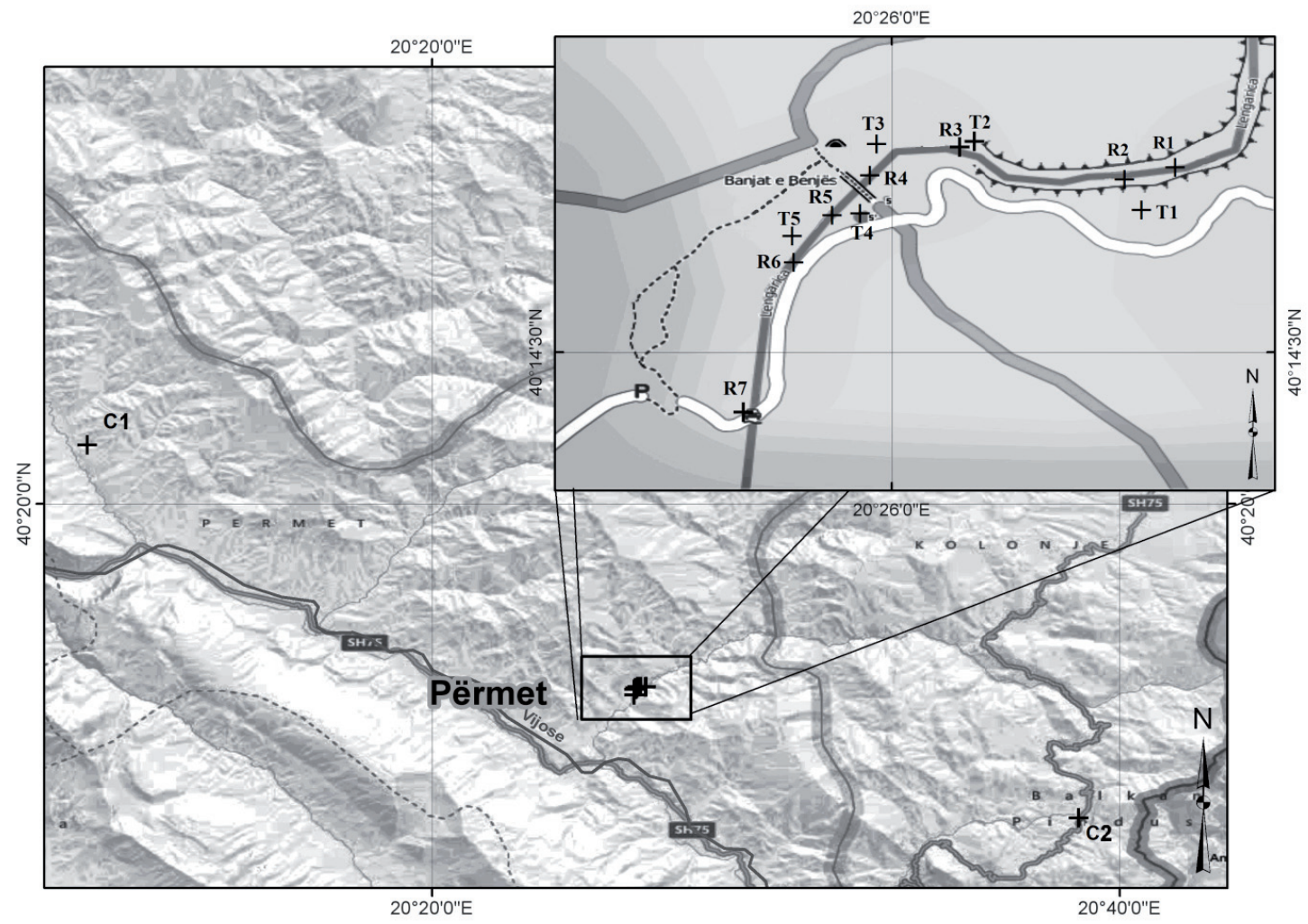

Fig. 1. Sampling sites in the Lëngaricës valley (Albania). Notations: R indicates sampling sites in the river, $\mathrm{T}$ indicates sampling sites in the thermal pond, and $\mathrm{C}$ indicates sampling sites in the control. 
thermal pond from which they were taken. Sediment samples were collected directly in the outflows of the river.

The water samples were collected from samples taken with plastic bottles, or parallel measurements were performed on-site. We used WTW pH 315i portable field instrumentation to measure $\mathrm{pH}$. A WTW Cond. 340i instrument was used to measure conductivity. For the laboratory process the samples were stored unconserved at $4^{\circ} \mathrm{C}$. In laboratory studies, chemical oxygen demand, chlorophyll-a, ammonia-ion, and carbon-dioxide concentration measurements were performed on the original sample by the methods described [16]. We used filtered samples to analyse the concentrations of nitrite, nitrate, ortho-phosphate, sulphate, carbonate, and hydrogen-carbonate. Samples were filtered with $0.45 \mu \mathrm{m}$ pore size filter paper, and then conserved in concentrated nitric acid (50ml sample of $0.5 \mathrm{ml}$ conc. $\mathrm{HNO}_{3}$ ). The $\mathrm{Ba}$, $\mathrm{Ca}, \mathrm{Cr}, \mathrm{Cu}, \mathrm{Fe}, \mathrm{K}, \mathrm{Li}, \mathrm{Mg}, \mathrm{Na}, \mathrm{Ni}, \mathrm{P}, \mathrm{Pb}, \mathrm{S}, \mathrm{Sr}$, and $\mathrm{Zn}$ concentrations in the samples were analysed by ICP-OES IRIS Intrepid II XSP Duo type devices.

For geochemical analysis, $0.1 \mathrm{~g}$ dry sediment samples were put in the same beakers. They were digested using $10 \mathrm{ml} \mathrm{65 \%}(\mathrm{m} / \mathrm{m})$ nitric acid and $2 \mathrm{ml} \mathrm{30 \%}(\mathrm{m} / \mathrm{m})$ hydrogen-peroxide at $80^{\circ} \mathrm{C}$ for 4 hours. Digested samples were diluted to $10 \mathrm{ml}$ using $1 \%(\mathrm{~m} / \mathrm{m})$ nitric acid. The concentrations of $\mathrm{Al}, \mathrm{Ba}, \mathrm{Ca}, \mathrm{Cd}, \mathrm{Co}, \mathrm{Cr}, \mathrm{Cu}, \mathrm{K}, \mathrm{Li}, \mathrm{Mg}$, $\mathrm{Mn}, \mathrm{Na}, \mathrm{Ni}, \mathrm{P}, \mathrm{Pb}, \mathrm{S}, \mathrm{Sr}$, and $\mathrm{Zn}$ in sediment samples was analysed by an ICP-OES IRIS Intrepid II XSP Duo device [17-18].

Our assessments of the effects of the water of the river and the thermal ponds were based on morphological traits, i.e., root length and the germination of white mustard seeds. The seeds were sterilized in $10 \%$ Na-hypochlorite solution for $20 \mathrm{~min}$ to prevent fungal growth. After sterilization, seeds were washed several times with distilled water [19]. A standard filter paper method [20] was used for the test. White mustard seeds (30 per replication, with three replications) were placed in Petri dishes $(\varnothing 15 \mathrm{~cm})$ on filter paper moistened with $20 \mathrm{ml}$ of solution [9]. For water toxicology $3 \mathrm{ml}$ of original water was used for each sample. For the sediment solution $2 \mathrm{~g}$ dry samples were diluted in $20 \mathrm{ml}$ of distilled water. The diluted samples were shaken for two hours and then the solutions were kept at room temperature for 24 hours. Petri dishes were maintained for 72 hours under dark conditions.

The SPSS/PC+ statistical software package was used during the calculations. The homogeneity of variances was tested by the Levene test. The physical and chemical parameters of the water and the sediment of the river, and of the thermal and control ponds were compared with ANOVA, which has also been used in earlier toxicological studies [21]. The root elongation and seed germination of $S$. alba were compared with GLM ANOVA [22]. To check significant differences we used Tukey's Multiple Comparison test. The correlation between the length of root and seed germination of $S$. alba and the value of the physicochemical parameters of the water and the sediment were analysed using the Pearson correlation [23].

\section{Results and Discussion}

Comparing the physicochemical parameters of the water, we found significant differences among the river, the thermal ponds, and the control ponds using ANOVA (Table 1). There were significant differences among the

Table 1. Physicochemical parameters $($ mean \pm SD) of water in the studied sites. Different letters indicate significant differences $(\mathrm{p}<0.05)$.

\begin{tabular}{|c|c|c|c|}
\hline $\begin{array}{c}\text { Parameters } \\
\text { (mg L } \mathrm{m}^{-1} \text { unless } \\
\text { otherwise noted) }\end{array}$ & $\begin{array}{l}\text { Control } \\
\text { ponds }\end{array}$ & $\begin{array}{l}\text { Thermal } \\
\text { ponds }\end{array}$ & River \\
\hline Temperature $\left({ }^{\circ} \mathrm{C}\right)$ & $28.1 \pm 1.9$ & $27.6 \pm 1.9$ & $26.8 \pm 2.1$ \\
\hline $\mathrm{pH}$ & $8.7 \pm 0.1^{\mathrm{a}}$ & $7.6 \pm 0.2^{\mathrm{b}}$ & $8.2 \pm 0.2^{\mathrm{c}}$ \\
\hline $\begin{array}{l}\text { Conductivity } \\
\left(\mu \mathrm{S} \mathrm{cm}^{-1}\right)\end{array}$ & $315 \pm 33^{\text {a }}$ & $2363 \pm 380^{\mathrm{b}}$ & $1166 \pm 632^{a}$ \\
\hline Suspended solids & $10.0 \pm 7.0^{\mathrm{a}}$ & $0.2 \pm 0.2^{\mathrm{ab}}$ & $10.3 \pm 5.2^{\mathrm{a}}$ \\
\hline $\mathrm{CO}_{2}$ & $3.8 \pm 1.8^{\mathrm{a}}$ & $11.3 \pm 1.3^{\mathrm{b}}$ & $5.0 \pm 1.5^{\mathrm{a}}$ \\
\hline $\mathrm{CO}_{3}^{2-}$ & $26.1 \pm 4.5$ & $31.8 \pm 3.5$ & $28.9 \pm 1.9$ \\
\hline $\mathrm{HCO}_{3}^{-}$ & $31.7 \pm 31.7^{\mathrm{a}}$ & $<6^{\mathrm{b}}$ & $<6^{\mathrm{b}}$ \\
\hline $\mathrm{SO}_{4}{ }^{2-}$ & $18.0 \pm 5.0^{\mathrm{a}}$ & $121.5 \pm 26.7^{\mathrm{b}}$ & $69 \pm 34^{\mathrm{a}}$ \\
\hline $\mathrm{Cl}^{-}$ & $7.2 \pm 0.3^{\mathrm{a}}$ & $603 \pm 122^{b}$ & $228 \pm 206^{a}$ \\
\hline $\begin{array}{c}\text { Chemical Oxygen } \\
\text { Demand }\end{array}$ & $0.7 \pm 0.6$ & $1.5 \pm 1.0$ & $1.4 \pm 0.6$ \\
\hline Chlorophyll-a & $3.1 \pm 0.9^{\mathrm{a}}$ & $0.4 \pm 0.5^{\mathrm{b}}$ & n.d. ${ }^{b}$ \\
\hline $\mathrm{PO}_{4}^{3-}$ & n.d. & $0.02 \pm 0.02$ & $0.02 \pm 0.02$ \\
\hline $\mathrm{NO}_{2}^{-}$ & $0.03 \pm 0.03$ & $0.05 \pm 0.02$ & $0.05 \pm 0.04$ \\
\hline $\mathrm{NO}_{3}^{-}$ & $0.1 \pm 0.1$ & $0.2 \pm 0.2$ & $0.2 \pm 0.1$ \\
\hline $\mathrm{NH}_{4}^{+}$ & $0.2 \pm 0.2$ & $0.7 \pm 0.5$ & $0.4 \pm 0.2$ \\
\hline Kjeldahl-nitrogen & $0.2 \pm 0.1^{\mathrm{a}}$ & $0.7 \pm 0.1^{\mathrm{b}}$ & $0.3 \pm 0.2^{\mathrm{a}}$ \\
\hline $\mathrm{Ba}$ & $0.1 \pm 0.01^{\mathrm{a}}$ & $0.2 \pm 0.04^{b}$ & $0.1 \pm 0.03^{\mathrm{a}}$ \\
\hline $\mathrm{Ca}$ & $33.3 \pm 5.9^{\mathrm{a}}$ & $140.2 \pm 20.8^{b}$ & $77.6 \pm 34.2^{\mathrm{a}}$ \\
\hline $\mathrm{Cr}$ & $0.5 \pm 0.1$ & $0.3 \pm 0.1$ & $0.4 \pm 0.1$ \\
\hline $\mathrm{Cu}$ & $0.02 \pm 0.01$ & $0.03 \pm 0.01$ & $0.03 \pm 0.01$ \\
\hline $\mathrm{Fe}$ & $0.8 \pm 0.3$ & $0.4 \pm 0.2$ & $0.4 \pm 0.2$ \\
\hline $\mathrm{K}$ & $0.3 \pm 0.0^{\mathrm{a}}$ & $16.5 \pm 4.4^{b}$ & $7.0 \pm 5.5^{\mathrm{a}}$ \\
\hline $\mathrm{Li}$ & $<0.01^{\mathrm{a}}$ & $1.0 \pm 0.4^{\mathrm{b}}$ & $0.4 \pm 0.4^{\mathrm{ab}}$ \\
\hline $\mathrm{Mg}$ & $24.7 \pm 2.6^{\mathrm{a}}$ & $30.4 \pm 0.3^{b}$ & $27.3 \pm 1.6^{\mathrm{a}}$ \\
\hline $\mathrm{Na}$ & $5.1 \pm 3.3^{\mathrm{a}}$ & $313.6 \pm 56.3^{b}$ & $128.1 \pm 98.4^{\mathrm{a}}$ \\
\hline $\mathrm{Ni}$ & $0.1 \pm 0.01^{\mathrm{a}}$ & $0.2 \pm 0.04^{b}$ & $0.1 \pm 0.05^{\mathrm{ab}}$ \\
\hline $\mathrm{P}$ & $0.2 \pm 0.1$ & $0.1 \pm 0.1$ & $0.2 \pm 0.1$ \\
\hline $\mathrm{Pb}$ & $0.03 \pm 0.0$ & $0.04 \pm 0.0$ & $0.07 \pm 0.06$ \\
\hline $\mathrm{S}$ & $15.0 \pm 9.1^{\mathrm{a}}$ & $161.3 \pm 47.3^{b}$ & $93.7 \pm 48.1^{\mathrm{ab}}$ \\
\hline $\mathrm{Sr}$ & $0.1 \pm 0.07^{\mathrm{a}}$ & $4.5 \pm 1.4^{\mathrm{b}}$ & $2.0 \pm 1.6^{\mathrm{ab}}$ \\
\hline $\mathrm{Zn}$ & $0.02 \pm 0.01$ & $0.09 \pm 0.10$ & $0.03 \pm 0.01$ \\
\hline
\end{tabular}


Table 2. Physicochemical and elemental parameters of sediment $($ mean \pm SD) in the studied sites. Different letters indicate significant differences $(\mathrm{p}<0.05)$.

\begin{tabular}{|c|c|c|c|}
\hline Parameters & $\begin{array}{c}\text { Control } \\
\text { ponds }\end{array}$ & Thermal ponds & River \\
\hline $\begin{array}{c}\text { Conductivity } \\
\left(\mu \mathrm{S} \mathrm{cm}^{-1}\right)\end{array}$ & $407 \pm 1.4$ & $557 \pm 207$ & $375 \pm 202.9$ \\
\hline $\mathrm{pH}$ & $7.5 \pm 0.1$ & $7.7 \pm 0.1$ & $7.8 \pm 0.1$ \\
\hline $\begin{array}{c}\text { Temperature } \\
\left({ }^{\circ} \mathrm{C}\right)\end{array}$ & $22.8 \pm 0.0$ & $22.6 \pm 0.2$ & $22.7 \pm 0.1$ \\
\hline $\begin{array}{c}\text { Organic } \\
\mathrm{matter}(\%)\end{array}$ & $7.9 \pm 5.3^{\mathrm{a}}$ & $2.8 \pm 0.4^{\mathrm{b}}$ & $3.6 \pm 1.1^{\mathrm{b}}$ \\
\hline $\begin{array}{c}\mathrm{Calcium}- \\
\left.\mathrm{carbonate}{ }^{\circ}\right)\end{array}$ & $10.0 \pm 5.0$ & $11.8 \pm 1.0$ & $11.8 \pm 4.1$ \\
\hline $\mathrm{Al}\left(\mathrm{g} \mathrm{kg}^{-1}\right)$ & $22.5 \pm 9$ & $18.1 \pm 6.2$ & $91.8 \pm 5.6$ \\
\hline $\mathrm{Ba}\left(\mathrm{mg} \mathrm{kg}^{-1}\right)$ & $76.3 \pm 36.2$ & $68.7 \pm 29.8$ & $44.3 \pm 8.0$ \\
\hline $\mathrm{Ca}\left(\mathrm{g} \mathrm{kg}^{-1}\right)$ & $84.2 \pm 53.4$ & $89.6 \pm 14.9$ & $88.6 \pm 21.3$ \\
\hline $\mathrm{Cd}\left(\mathrm{mg} \mathrm{kg}^{-1}\right)$ & $3.6 \pm 0.9$ & $2.8 \pm 0.6$ & $3.3 \pm 0.7$ \\
\hline $\mathrm{Co}\left(\mathrm{mg} \mathrm{kg}^{-1}\right)$ & $79.3 \pm 63.6$ & $39.3 \pm 6.8$ & $52.0 \pm 11.0$ \\
\hline $\mathrm{Cr}\left(\mathrm{mg} \mathrm{kg}^{-1}\right)$ & $537 \pm 360$ & $332 \pm 94$ & $453 \pm 122$ \\
\hline $\mathrm{Cu}\left(\mathrm{mg} \mathrm{kg}^{-1}\right)$ & $46.8 \pm 1.2$ & $45.4 \pm 8.7$ & $44.1 \pm 8.0$ \\
\hline $\mathrm{K}\left(\mathrm{mg} \mathrm{kg}^{-1}\right)$ & $779 \pm 376$ & $866 \pm 431$ & $826 \pm 241$ \\
\hline $\left.\mathrm{Li} \mathrm{(mg} \mathrm{kg}{ }^{-1}\right)$ & $38.6 \pm 25.8^{\mathrm{a}}$ & $64.5 \pm 12.1^{\mathrm{b}}$ & $60.7 \pm 9.0^{\mathrm{ab}}$ \\
\hline $\mathrm{Mg}\left(\mathrm{g} \mathrm{kg}^{-1}\right)$ & $29.5 \pm 15.0^{\mathrm{a}}$ & $36.0 \pm 8.3^{\mathrm{ab}}$ & $47.6 \pm 6.7^{\mathrm{b}}$ \\
\hline $\mathrm{Mn}\left(\mathrm{mg} \mathrm{kg}^{-1}\right)$ & $810 \pm 303$ & $652 \pm 73$ & $747 \pm 87$ \\
\hline $\mathrm{Na}\left(\mathrm{mg} \mathrm{kg}^{-1}\right)$ & $246 \pm 101^{\mathrm{a}}$ & $708 \pm 131^{\mathrm{b}}$ & $612 \pm 192^{\mathrm{b}}$ \\
\hline $\mathrm{Ni}\left(\mathrm{mg} \mathrm{kg}^{-1}\right)$ & $1,064 \pm 960$ & $524 \pm 172$ & $802 \pm 220$ \\
\hline $\mathrm{P}\left(\mathrm{mg} \mathrm{kg}^{-1}\right)$ & $1,404 \pm 786$ & $980 \pm 211$ & $853 \pm 142$ \\
\hline $\mathrm{Pb}\left(\mathrm{mg} \mathrm{kg}^{-1}\right)$ & $30.3 \pm 8.0$ & $27.8 \pm 1.9$ & $29.0 \pm 4.4$ \\
\hline $\left.\mathrm{S} \mathrm{(mg} \mathrm{kg}{ }^{-1}\right)$ & $4,991 \pm 216$ & $13,351 \pm 9,267$ & $7,480 \pm 2,135$ \\
\hline $\mathrm{Sr}\left(\mathrm{mg} \mathrm{kg}^{-1}\right)$ & $118 \pm 128^{\mathrm{a}}$ & $283 \pm 84^{\mathrm{b}}$ & $217 \pm 54^{\mathrm{b}}$ \\
\hline $\left.\mathrm{Zn}{ }^{-1}\right)$ & $102 \pm 12$ & $94.6 \pm 23.7$ & $103 \pm 18$ \\
\hline
\end{tabular}

a)

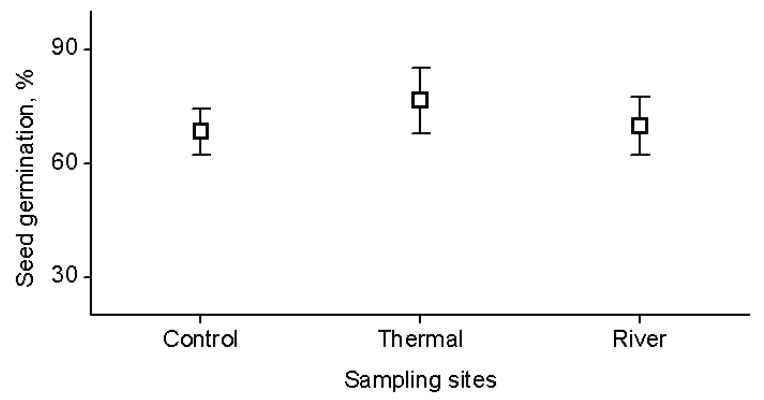

studied sites in the $\mathrm{pH}$, conductivity, suspended solids, and concentrations of carbon dioxide, hydrogen-carbonate, chloride-ion, sulphate-ion, chlorophyll-a, and Kjeldahlnitrogen, and the following elements: $\mathrm{Ba}, \mathrm{Ca}, \mathrm{K}, \mathrm{Li}, \mathrm{Mg}$, $\mathrm{Na}, \mathrm{Ni}, \mathrm{S}$, and $\mathrm{Sr}(\mathrm{p}<0.05)$.

Comparing the physicochemical parameters of the sediment, significant differences were found among the river, the thermal ponds, and the control ponds using ANOVA in the concentrations of the following elements: $\mathrm{Li}, \mathrm{Mg}, \mathrm{Na}, \mathrm{Sr}$, and the content of organic matter among the studied sites $(\mathrm{p}<0.05)$ (Table 2). Based on Tukey's comparison test, the organic matter content was significantly higher in the control ponds than in the thermal ponds and the river. The concentrations of $\mathrm{Li}, \mathrm{Na}$, and $\mathrm{Sr}$ were significantly higher in the thermal ponds than in the control ponds and the river. The concentration of $\mathrm{Mg}$ was significantly higher in the river than in the thermal and control ponds.

We found no significant difference in the germination percentage of $S$. alba seeds among the three water types $(\mathrm{p}=0.136)$ (Fig. 2a). There were significant differences in the root elongation of $S$. alba seeds in the water of the river, the thermal ponds, and the control ponds $(p=0.049)$ (Fig. 2b).

Our results did not show any significant differences among the sediments from the river, the thermal ponds, and the control ponds in terms of seed germination $(p=0.576)$ (Fig. 3a). In spite of this, significant differences in root elongation were found among the three water types, based on the sediment. A significantly greater root length was found in the sediment of thermal ponds than in the river sediment $(p=0.013)$ (Fig. 3b). However, no significant differences were found between the control and thermal ponds, and between the control ponds and the river.

Based on the Pearson correlation, a positive correlation was found between root length and the $\mathrm{Cu}(\mathrm{r}=0.684$, $\mathrm{p}=0.007), \mathrm{K}(\mathrm{r}=0.745, \mathrm{p}=0.002)$, and $\mathrm{Li}(\mathrm{r}=0.644$, $\mathrm{p}=0.013)$ concentrations in the sediment. In the case of germination, positive correlations were found between germination and the concentrations of $\mathrm{Cu}(\mathrm{r}=0.543$, $\mathrm{p}=0.045)$ and $\mathrm{Li}(\mathrm{r}=0.594, \mathrm{p}=0.025)$ in the sediment,

b)

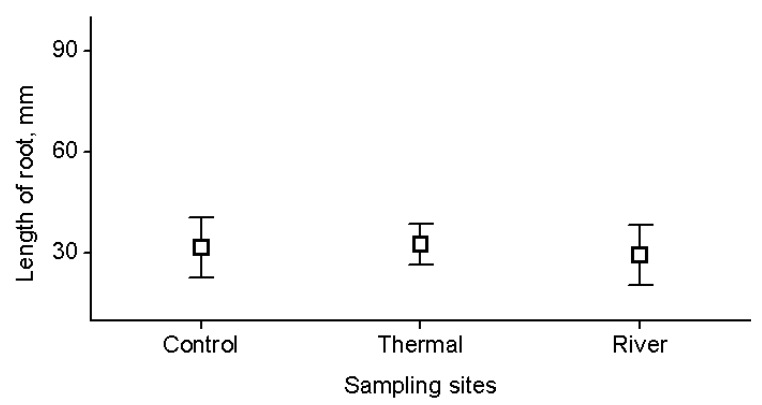

Fig. 2. The effect of the water of the control ponds, the thermal pond, and the river on a) seed germination (mean \pm SD) and b) root elongation (mean $\pm \mathrm{SD}$ ). 
a)

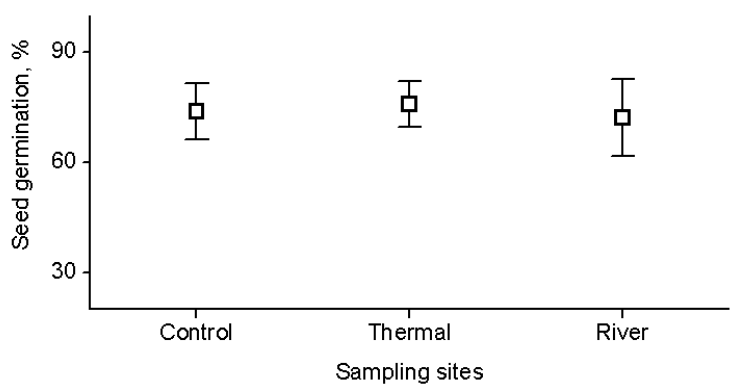

b)

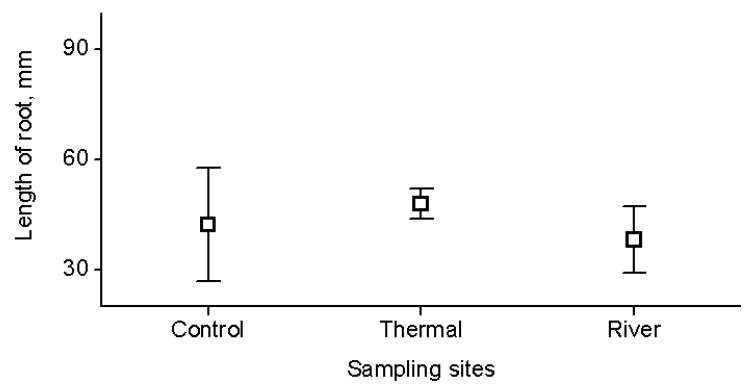

Fig. 3. The effect of the sediments from the control ponds, the thermal ponds, and the river on a) seed germination (mean \pm SD) and b) root elongation (mean $\pm \mathrm{SD})$.

and the concentrations of carbon-dioxide $(\mathrm{r}=0.558$, $\mathrm{p}=0.038)$, sulphate-ion $(\mathrm{r}=0.553, \mathrm{p}=0.014), \mathrm{Ba}$ $(\mathrm{r}=0.650, \mathrm{p}=0.012), \mathrm{Mg}(\mathrm{r}=0.648, \mathrm{p}=0.012)$, and $\mathrm{Ni}$ $(\mathrm{r}=0.560, \mathrm{p}=0.037)$ in the water. A negative correlation was found between germination and the $\mathrm{pH}$ value of the water $(r=-0.670, p=0.009)$. Among the minerals studied, $\mathrm{Cu}$ was the most effective metal in terms of the inhibition of plant roots [24-25]. At the same time, similar to an earlier study, our results indicated that $\mathrm{Cu}$ is an essential nutrient for plants, and that the amount of $\mathrm{Cu}$ absorbed is a stimulant for root development and seed germination [26]. The positive correlation between root length and $\mathrm{K}$ concentration in the sediment indicated that $\mathrm{K}$ is also one of the most important nutrients and is essential for plant growth and development [27]. Earlier studies have demonstrated that lithium is a phytotoxic element, but many results were unclear and the interpretation of these results needs more information about the toxicity of lithium in plants [28]. Contrary to these earlier studies, our results demonstrated that $\mathrm{Li}$ is a stimulant for both root development and seed germination. Contrary to our results, Suwa et al. [29] reported that barium has phytotoxic effects on plants by inhibiting phytosynthesis, while in our study the positive correlation between the Ba concentration and seed germination indicated the stimulant effect of $\mathrm{Ba}$ in water. Similarly to $\mathrm{Ba}, \mathrm{Mg}$ also had a stimulant effect on seed germination in our study. Mg plays an important role in many biological processes and Leskó et al. [30] demonstrated that $\mathrm{Mg}$ could reduce the negative effects of heavy metals in seedlings. Ni is an essential micronutrient for plants, but at excess concentrations it may inhibit growth and cause chlorosis and necrosis [31]. The positive correlation between the $\mathrm{Ni}$ concentration of water and seed germination indicated that Ni may be a stimulant for seed germination of S. alba. Zhao et al. [32] demonstrated that reduced alkaline stress increased the survival rate and growth of seedlings. The thermal ponds - similarly to the river - were alkaline, based on the $\mathrm{pH}$ value of their water. Thus, the alkaline $\mathrm{pH}$ had a negative effect on $S$. alba seed germination. Contrary to our results, Ma et al. [33] demonstrated that a high alkaline $\mathrm{pH}$ had no negative effect on seed germination.
Based on the physicochemical parameters of water, our results demonstrated that the conductivity and concentrations of sulphate, chloride, carbon-dioxide, Ba, $\mathrm{Ca}, \mathrm{K}, \mathrm{Li}, \mathrm{Mg}, \mathrm{Na}, \mathrm{S}$, and $\mathrm{Sr}$ were significantly higher in the thermal ponds than in the river and the control ponds. In the case of the sediments, significantly higher $\mathrm{Li}, \mathrm{Na}$, and $\mathrm{Sr}$ concentrations were found in the thermal ponds than in the river and the control ponds. Agolli et al. [34] reported that it is mainly the high sulphurous content of the studied thermal ponds that may cause the curative effects for chronic rheumatism, and diseases of the stomach and skin. Similar to other findings, our results demonstrated that remarkable differences were not found among thermal waters, except in the cases of $\mathrm{Fe}, \mathrm{K}, \mathrm{Li}$, $\mathrm{P}, \mathrm{S}$, and $\mathrm{Sr}[3,15]$. Thus our results indicated that these elements have curative effects for these diseases.

\section{Conclusions}

Contrary to earlier findings about the negative effects of high levels of nutrients, our study demonstrated that the water and sediment of thermal ponds had stimulant effects on the ecosystem based on the toxicological method of the root elongation of $S$. alba. At the same time, our results indicate that among the physicochemical parameters, $\mathrm{Cu}$, $\mathrm{K}$, and $\mathrm{Li}$ were stimulants for root elongation, while $\mathrm{Cu}$, $\mathrm{Li}, \mathrm{Ba}, \mathrm{Mg}, \mathrm{Ni}$, carbon-dioxide, and sulphate-ion had a stimulant effect on seed germination. In our case the effect of thermal ponds with high nutrient content was a stimulant, which is due to the location of Albania along a low geothermal gradient.

\section{Acknowledgements}

Our research was partially supported by the Internal Research Project of the University of Debrecen (E. Simon), by the TÁMOP 4.2.1./B-09/1/KONV-2010-0024 project, and by the SROP-4.2.2.B-15/1/KONV20150001 project. 


\section{References}

1. CRUZ J.V., FRANCA Z. Hydrogeochemistry of thermal and mineral water thermal waters of the Azores archipelago (Portugal). J. Volcanol. Geoth. Res. 151, 382, 2006.

2. MICHALIK A. The use of chemical and cluster analysis for studying thermal water quality in Świętokrzyski National Park. Pol. J. Environ. Stud. 17, 357, 2008.

3. ZIJA K., KODHELAJ N., BOZGO S., FRASHËRI A., CELA B., ALETI R., THODHORJANI S., ZEQIRAJ D. Potential of Bënja geothermal spring for direct utilization. J. Earth Sci. Eng., 4, 684, 2014.

4. PAPIC P. (eds.) Mineral and thermal waters of South-eastern Europe. Springer, 2015.

5. PAN M., CHU L.M. Phytotoxicity of veterinary antibiotics to seed germination and root elongation of crops. Ecotox. Environ. Safe 126, 228, 2016.

6. PARK J., YOO J.H., DEPUYDT S., OH, J.W., YO Y.M., KIM K., BROWN M.T., HAN T. The sensitivity of a hydroponic lettuce root elongation bioassay to metals, phenol and wastewaters. Ecotox. Environ. Safe 126, 147, 2016.

7. PHOUNGTHONG K., ZHANG H., SHOO L.M., HE, P.J. Variation of the phytotoxicity of municipal solid waste indicator bottom ash on wheat (Triticum aestivum L.) seed germination with leaching conditions. Chemosphere 146, 547, 2016.

8. WIERZBICKA M., OBIDZINSKA J. The effect of lead on seed imbibition on germination in different plan species. Plant Sci. 37, 155, 1998.

9. GVOZDENAC S., INĐIĆ D., VUKOVIĆ S. Phytotoxicity of chlorpyrifos to white mustard (Sinapis alba L.) and maize (Zea mays L.): Potential indicators of insecticide presence in water. Pesticid. Fitomed. 28, 265, 2013.

10. MOLNÁROVÁ M., FARGASOVÁ A. Relationship between various physiological and biochemical parameters activated by cadmium in Sinapis alba L. and Hordeum vulgare L. Ecol. Eng. 49, 65, 2012.

11. BEDELL J.P., BAZIN C., SARRAZIN B., PERRODIN Y. Assessment of the phytotoxicity of seaport sediment in the framework of a Quarry-Deposit Scenario: Germination test of sediments aged artificially by column leaching. Arch. Environ. Con Tox. 65, 1, 2013.

12. PLOCINICZAK T., KUKLA M., WATROBA R., PIOTROWSKA-SEGET Z. The effect of soil bioaugmentation with strains of Pseudomonas on $\mathrm{Cd}, \mathrm{Zn}$ and $\mathrm{Cu}$ uptake by Sinapis alba L. Chemosphere 91, 1332, 2013.

13. DODDS W.K.K., WELCH, E.B. Establishing nutrient criteria in streams. J. N. Am. Benthol. Soc. 19, 186, 2000.

14. KABO M. Gjeografia Fizike e Shqipërisë, Vol. I. and II. Albanian Academy of Sciences. Geographic Studies Centre, Tirana, 400, 1990.

15. ORUCI S. Bio-ecological data on Amphibians of thermal water of Permeti Area (South Albania). In: BALWOIS Conference Proceedings, Orhid, Republic of Macedonia Art 267, 1, 2010 .

16. NÉMETH J. A biológiai vízminősítés módszerei. Methods for water quality management (in Hungarian). Környezetgazdálkodási Intézet TOI Környezetvédelmi Tájékoztató Szolgálat, Budapest, 1998.

17. NGUYEN H.L., BRAUN M., SZALOKI I., BAEYENS W., VAN GRIEKEN R., LEERMAKERS M. Tracing the metal pollution history of the Tisza river through the analysis of a sediment depth profile. Water Air Soil Poll. 200, 119, 2008.

18. PAPP I., BRAUN M., SZALÓKI I., LEERMAKERS M. Investigation of the effects of the Baia Borsa pollution event in the sediment of the Boroszlókert Oxbow lake of the Tisza. Acta Geogr. Geol. Meteorol. Debrecina, 2, 181, 2007.

19. FARGASOVÁ A., BEINROHR E. Metal interactions in accumulation of $\mathrm{V}^{5+}, \mathrm{Ni}^{2+}, \mathrm{Mo}^{6+}, \mathrm{Mn}^{2+}$ and $\mathrm{Cu}^{2+}$ in under and above-ground parts of Sinapis alba. Chemosphere, 36, 1305, 1998.

20. International Seed Testing Association. International Rules for Seed Testing. ISTA. Switzerland, 2001.

21. GAD S.C. An approach to the design and analysis of screening studies in toxicology. Int. J. Toxicol. 7, 127, 1988.

22. BURCZYNSKI M.E., MCMILLION M., CIERVO J., LI L., PARKER J.B., DUNN R.T., HICKEN S., FARR S., JOHNSON M.D. Toxicogenomics-based discriminant of toxic mechanism in HepG2 human hepatoma cells. Toxicol. Sci. 58, 399, 2000.

23. ZAR I.H. Biostatistical Analysis. Prentice Hall, N.J., 1996.

24. YOON J., CAO X., ZHOU Q., MA L.Q. Accumulation of $\mathrm{Pb}, \mathrm{Cu}$, and $\mathrm{Zn}$ in native plants growing on a contaminated Florida site. Sci. Total Environ. 368, 456, 2006.

25. TANGAHU B.V., ABDULLAH S.R.S., BASRI H., IDRIS M., ANUAR N., MUKHLISIN M. A review on heavy metals ( $\mathrm{As}, \mathrm{Pb}$, and $\mathrm{Hg}$ ) uptake by plants through phytoremediation. Int. J. Chem. Engineering 2011, 1, 2011.

26. AGBODJATO N.A., NOUMAVO P.A., ADJANOHOUN A., AGBESSI L., BABA-MOUSSA L. Synergistic effects of plant growth promoting Rhizobacteria and Chitosan on In Vitro seeds germination, greenhouse growth, and nutrient uptake of maize (Zea mays L.). Biotech. Res. Int. 2016, 1, 2016.

27. PETTIGREW W.T. Potassium influences on yield and quality production for maize, wheat, soybean and cotton. Physiol. Plantarum 133, 670, 2008.

28. ARAL H., VECCHIO-SADUS A. Toxicity of lithium to humans and the environment - A literature review. Ecotox. Environ. Safe. 70, 349, 2008.

29. SUWA R., JAYACHANDRAN K., NGUYEN N.T., BOULENOUAR A., FUJITA K., SANEOKA H. Barium toxicity effects in soybean plants. Arch. Environ. Con Tox. 55, 397, 2008.

30. NAGAJYOTI P.C., LEE K.D., SREEKANTH T.V.M. Heavy metals, occurrence and toxicity for plants: a review. Environ. Chem. Lett. 8, 199, 2010.

31. CHEN C., HUANG D., LIU J. Functions and toxicity of nickel in plants: Recent advances and future prospects. Clean-Soil, Air, Water 37, 304, 2009.

32. ZHAO Y., LU Z., HE L. Effects of saline alkaline stress on seed germination and seedling growth of Sorghum bicolor (L.) Moench. Appl. Biochem. Biotech. 173, 1680, 2014.

33. MA H., YANG H., LÜ X., PAN Y., WU H., LIANG Z., OOI M.K.J. Does high $\mathrm{pH}$ give a reliable assessment of the effect of alkaline soil on seed germination? A case study with Leymus chiensis (Poaceae). Plant Soil 394, 35, 2015.

34. AGOLLI M., TERPO M., TERP D.M., MEÇI E. TouristEnvironmental assessment of Permet district, traditional food processing and the typical products of the area. Mediterr. J. Soc. Sci. 5, 36, 2014 